\title{
Citrus Greening: Management Strategies and Their Economic Impact
}

\author{
Sheng $\mathrm{Li}$ and Feng $\mathrm{Wu}$ \\ Gulf Coast Research and Education Center, University of Florida, 14625 \\ County Road 672, Wimauma, FL 33598
}

\section{Yongping Duan}

U.S. Horticultural Research Laboratory, U.S. Department of AgricultureAgricultural Research Service, 2001 South Rock Road, Fort Pierce, FL 34945

\section{Ariel Singerman}

Food and Resource Economics Department, Citrus Research and Education Center, University of Florida, 700 Experiment Station Road, Lake Alfred, FL 33850

\section{Zhengfei Guan}

Food and Resource Economics Department, Gulf Coast Research and Education Center, University of Florida, 14625 County Road 672, Wimauma, FL 33598

Additional index words. citrus huanglongbing, cost-effective treatment, HLB management

\begin{abstract}
Citrus huanglongbing (HLB), or greening, is the most destructive citrus disease worldwide and is threatening the sustainability of the industry in major citrus-growing regions. Various treatments have been proposed in the literature to manage the disease. We review such literature and conduct an economic analysis based on the reported treatment effects on fruit yield and quality to identify cost-effective management strategies. Our results suggest that, among the treatments we reviewed, broadspectrum insecticides provide the only cost-effective strategy for mitigating the impact of the disease. Our findings and discussion should help growers, policymakers, and other stakeholders make informed decisions in the search for effective, sustainable, and environmentally friendly treatments and policies against HLB.
\end{abstract}

Citrus is one of the top specialty crops grown in the United States. It ranks third in terms of bearing area (after almonds and grapes) and accounts for $16 \%$ of the total value of U.S. fruit production. On the demand side, citrus juice is the major fruit drink nationwide, accounting for nearly half of the domestic fruit juice market (USDAERS, 2018). During the 2016-17 season, the U.S. citrus industry contributed to the nation's economy by generating over $\$ 15$ billion and over 70,000 jobs. In recent years, however, the U.S. citrus industry has suffered major production losses due to citrus huanglongbing (HLB), or greening disease. The disease is caused by the bacterium Candidatus Liberibacter asiaticus (CLas), and it is transmitted by an insect vector [Asian citrus psyllid (ACP), Diaphorina citri] in the United States. The disease can cause a significant reduction in fruit quality and severely

Received for publication 4 Nov. 2019. Accepted for publication $13 \mathrm{Feb} .2020$.

Published online 23 March 2020.

Z.G. is the corresponding author. E-mail: guanz@ ufl.edu.

This is an open access article distributed under the CC BY-NC-ND license (https://creativecommons. org/licenses/by-nc-nd/4.0/). debilitate citrus trees, resulting in a significant yield loss (Iftikhar et al., 2016). Trees affected by HLB can become unproductive within 2 to 5 years and their lifespan can be reduced from 50 years to $7-10$ years (Ehsani et al., 2016; Jia et al., 2017). Thus, HLB has become the greatest challenge for U.S. citrus growers and the industry, particularly in Florida (Singerman and Rogers, 2020).

Florida is the largest orange producer in the United States, and over $90 \%$ of its crop is processed into juice. Florida is the state that has been impacted the most by HLB. The estimated damage of the disease over the past 5 years amounts to over $\$ 1$ billion per year, with nearly 5000 jobs lost annually. Grovebearing area in Florida has declined by $30 \%$ since the outbreak of the disease in 2005 , along with a $74 \%$ decline in production (Fig. 1) (Court et al., 2017). It is estimated that $90 \%$ of the acreage and $80 \%$ of citrus trees in Florida are affected by the disease (Singerman and Useche, 2017).

Due to the impact of HLB in Florida, since the 2016-17 season, California has become the largest citrus producer in the United States. California produces over $80 \%$ of the nation's fresh oranges despite HLB being discovered in California in 2012. Since then, many counties have been infested with ACP, including San Diego, Imperial, Riverside, San Bernardino, Orange, Los Angeles, Santa Barbara, and Ventura. Host plants infected with HLB and/or ACP have been found to be positive for CLas in Los Angeles, Orange, San Bernardino, and Riverside counties. Lopez and Durborow (2015) estimated that even if California aggressively combats HLB, the economic loss will still be $\$ 2.2$ billion over the next 20 years. Currently, a voluntary area-wide pest management program is in place, and the California Department of Food and Agriculture has implemented an action plan to manage ACP and HLB. The plan includes an eradication program of diseased trees, the use of pesticide applications and biological control, a statewide early detection program, and a regulatory program for ACP and HLB.

Most commercial cultivated citrus varieties are susceptible to CLas infection. And, despite significant scientific research efforts, there is yet no cure for HLB in commercial settings. Some of the strategies proposed for vector control and disease treatment include chemotherapy (Zhang et al., 2014), foliar sprays (Spann et al., 2011), thermotherapy (Hoffman et al., 2013), biological control (Alvarez et al., 2016; Cazorla and Mercado-Blanco, 2016), and tree replacement (Gottwald, 2010; Martini et al., 2015). Some scientists are looking into using transgenic citrus to cope with the disease, but this approach faces both biological and economic challenges. Transgenics have a high cost of development and would require planting new trees.

Some previous studies have reviewed the effects of management strategies against HLB, including chemical control (Blaustein et al., 2018), insecticides (Boina and Bloomquist, 2015), nutritionals (Xia et al., 2011), biological control (Grafton-Cardwell et al., 2013), and other treatments (Munir et al., 2017). However, those studies focused on the comparison of different practices within one strategy and their effects on controlling ACP, reducing/preventing HLB incidence, and on yield. A comprehensive analysis of the costs and benefits of those strategies and a cross comparison among them have never been conducted. Thus, the aim of this article is 2fold. First, to provide an overview of the HLB management strategies proposed in the literature with an emphasis on their effects on crop yield, costs, and benefits. Second, to assess the economic impact of the major proposed treatments to cope with the disease and analyze their cost-effectiveness. In the next section, we review management practices for HLB control, and in the following section we present the analysis of their economic performance. The final section presents major findings and recommendations.

\section{Management Practices for HLB Control}

In this section, we review the literature on HLB management practices, focusing on the economic impact of major treatments to cope with the disease, including antibiotics, 


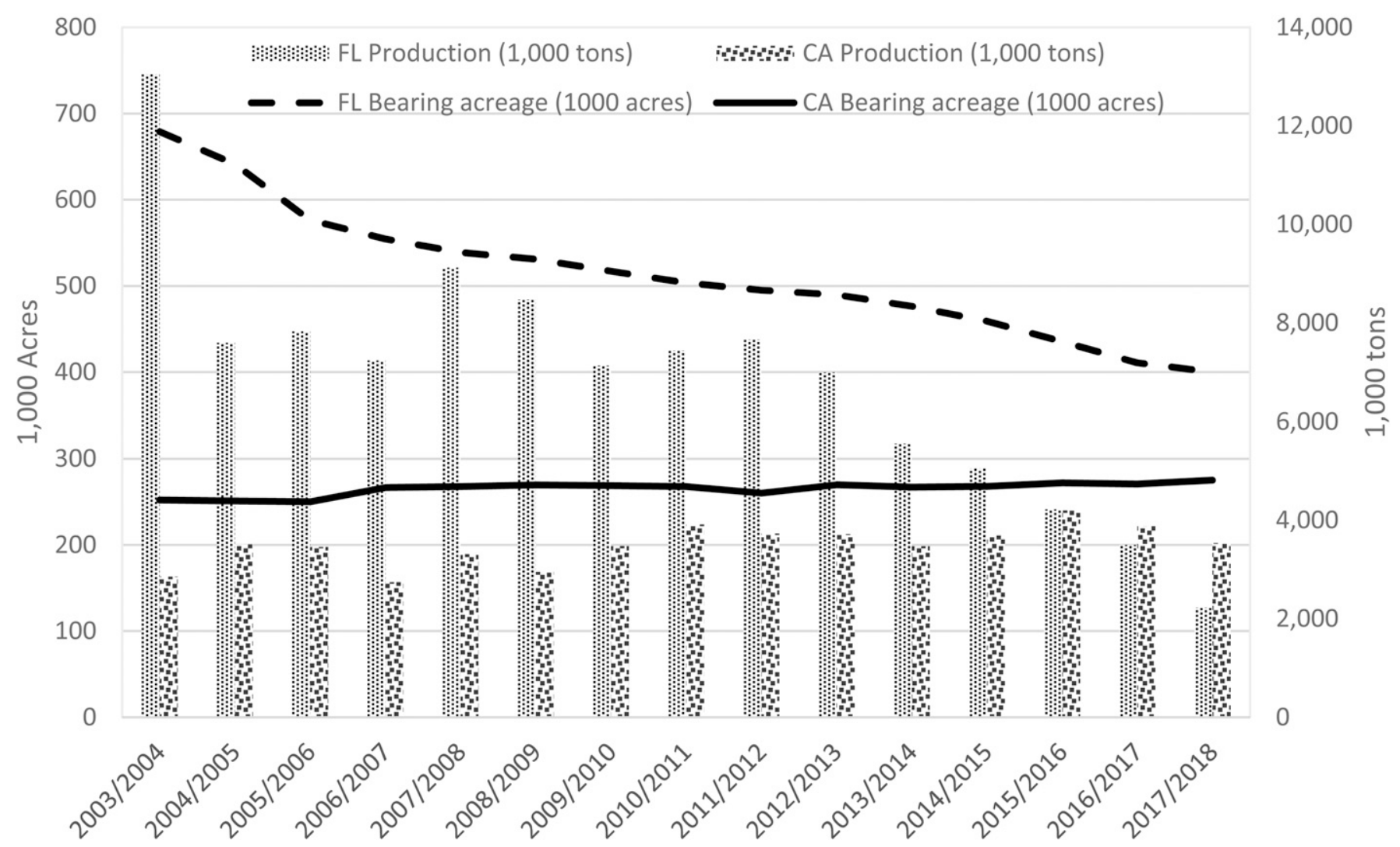

Fig. 1. Changes on bearing acreage and production in Florida and California.

insecticide applications, enhanced foliar nutritional programs, thermotherapy, and biological control. The cost-effectiveness of each type of treatment is estimated by computing the difference between associated benefits and costs. For our calculations, we assume tree density to be 134 trees per acre, which is the average grove density in Florida according to data from the U.S. Department of Agriculture - National Agricultural Statistics Service (USDA-NASS). In addition, we set the 2016-17 season as our baseline because it is the most recent year for which final estimates are available with no extreme weather events (i.e., hurricanes). In that season, the average yield per tree was 1.37 boxes, and the on-tree price was $\$ 11.82$ per box. For each treatment that we analyze, we compute the yield change in percentage terms relative to the control group reported in the literature. The associated benefits (revenue) of treatments are calculated by multiplying the yield change from proposed treatments by the orange on-tree price. The cost of the treatment includes material cost (if applicable) and application cost (labor, equipment, etc.). The profit and benefit-cost ratio (BCR) for each treatment are calculated by subtracting costs from benefits and by dividing benefits by costs, respectively.

$H L B$ control with antibiotics. The effectiveness of using antibiotics to cope with plant diseases has been under debate for decades. The widespread use of antibiotics is controversial due to public concerns regarding their potential negative effects on human health and the development of antibiotic-resistant bacteria (Aćimović et al., 2015; Stockwell and Duffy, 2012). Moreover, even though some antibiotic treatments have been found to be biologically effective to control plant diseases, they had to be abandoned partly due to their prohibitive costs in the field. Such was the case for the use of tetracycline in the 1970s, which seemed to be a promising treatment but was later discontinued due to both phytotoxicity and high costs (Aldeek et al., 2015, 2016). Streptomycin and oxytetracycline (OTC) have also been used in the United States for over 50 years, but their use has been restricted to only a few bacterial plant diseases due to their high cost and the development of antibiotic resistance (Blaustein et al., 2018; Sundin and Wang, 2018).

Studies have documented the response of HLB-affected trees to antibiotics when using different application methods, namely, foliar sprays, root drench, and trunk injections (Puttamuk et al., 2014; Zhang et al., 2011, 2012, 2013). Trunk injections of antibiotics have been found to have a higher efficacy compared with soil drenching and foliar sprays (Zhang et al., 2011). However, the costs associated with trunk injections may restrict their use on a large scale. Dixon et al. (2014) showed that the total cost of the injection of antibiotics was about $\$ 5$ per tree (i.e., $\$ 1$ for antibiotics, $\$ 1.50$ for injection devices, and $\$ 2.50$ for labor and other). Using data collected from growers (Singerman, 2019), we estimate the application cost for foliar sprays to be $\$ 180$ per acre (six applications per season at $\$ 30$ per application). Following application recommendations from scientists at the University of Florida Citrus Research and Education Center, the associated cost of materials (i.e., antibiotics) is estimated to range between $\$ 110$ and $\$ 165$, depending on the citrus variety.

In Table 1, we summarize the results of the studies that have reported changes in citrus yield of treated trees using antibiotics through field trials and greenhouse experiments. Shokrollah et al. (2011) conducted grouped treatments on infected citrus in Malaysia and found that injecting antibiotics $+\mathrm{GA}_{3}$ was the most effective treatment (with a $231 \%$ higher fruit yield relative to untreated trees). Hu and Wang (2016) found a lower yield increase ( $15 \%$ on average) in OTC treatment experiments in Florida using trunk injection with varying numbers of injection ports. Hu et al. (2017) found a significant yield increase in sweet orange trees and better fruit quality by applying eight plant 
Table 1. Impact of antibiotics and plant defenses on fruit yield and profit.

\begin{tabular}{|c|c|c|c|c|c|c|}
\hline Treatment & Impact on yield ${ }^{z}$ & Cost $(\$)^{y}$ & Benefit $(\$)^{x}$ & $\mathrm{BCR}^{\mathrm{w}}$ & Location & Reference \\
\hline \multirow[t]{3}{*}{$\begin{array}{l}\text { Oxytetracycline hydrochloride } \\
\text { (OTC) (trunk injection) }\end{array}$} & $\begin{array}{l}\text { Much higher fruit weight than } \\
\text { untreated trees }\end{array}$ & - & - & - & Malaysia, 2008 & Shokrollah et al. (2011) \\
\hline & Average yield increased by $15 \%$ & 609 & 397 & 0.65 & FL, 2015-16 & $\mathrm{Hu}$ and Wang (2016) \\
\hline & Yield increased by $38 \%$ to $52 \%$ & $505-587$ & $943-1284$ & $1.87-2.19$ & FL, 2014-16 & Hu et al. (2017) \\
\hline Penicillin (trunk injection) & $50 \%$ to $60 \%$ increase in yield & $550-560$ & $1240-1676$ & $2.2-3.5$ & FL, 2014-16 & Hu et al. (2017) \\
\hline Streptomycin sulfate & $44 \%$ to $47 \%$ increase in yield & $552-575$ & $1070-1141$ & $1.9-2.0$ & FL, 2014-16 & Hu et al. (2017) \\
\hline \multirow[t]{2}{*}{$\beta$-aminobutyric acid } & Yield increased by less than $3 \%$ & 618 & 67 & 0.1 & FL, 2014-16 & Hu et al. (2017) \\
\hline & $12 \%$ to $40 \%$ increase in yield & $540-590$ & $308-870$ & $0.5-1.4$ & FL, 2013-14 & Li et al. (2015) \\
\hline \multirow[t]{2}{*}{ INA } & Yield increased by nearly $10 \%$ & 586 & 235 & 0.4 & FL, 2014-16 & Hu et al. (2017) \\
\hline & Yield increased by nearly $2 \%$ to $40 \%$ & $548-630$ & $52-210$ & $0.1-0.3$ & FL, 2013-14 & Li et al. (2015) \\
\hline \multirow[t]{2}{*}{ Others (i.e., BTH, DDG) } & Yield changed from $-6 \%$ to $28 \%$ & $513-616$ & $-135-678$ & $-0.24-1.17$ & FL, 2014-16 & Hu et al. (2017) \\
\hline & Yield changed from $-6 \%$ to $31 \%$ & $502-649$ & $-151-720$ & $-0.28-1.01$ & FL, 2013-14 & Li et al. (2015) \\
\hline
\end{tabular}

${ }^{\mathrm{z}}$ The results are calculated based on data in the existing studies.

${ }^{\mathrm{y}}$ Costs include materials and labor and are adjusted by annual tree density.

${ }^{\mathrm{x}}$ Prices used in calculating benefits are the annual average on-tree price from USDA-NASS.

${ }^{\mathrm{w}} \mathrm{BCR}$ denotes Benefit-to-Cost Ratio.

Table 2. Impact of using insecticides on fruit yield and profit.

\begin{tabular}{|c|c|c|c|c|c|c|}
\hline Treatment & Impact on yield ${ }^{z}$ & $\operatorname{Cost}(\$)^{\mathrm{y}}$ & Benefit $(\$)^{x}$ & $\mathrm{BCR}^{\mathrm{w}}$ & Location & Reference \\
\hline 7 insecticides & $\begin{array}{l}\text { Increased by } 4 \mathrm{~kg} \text { per tree, and yield } \\
\text { changed from }-10 \% \text { to } 17 \%\end{array}$ & 279 & $-301-435$ & $-1.1-1.6$ & FL, 2012 & Stansly and Roka (2013) \\
\hline $10+$ insecticides & Yield changed from $-3.7 \%$ to $29 \%$ & $99-278$ & $-110-830$ & $-1.1-5.9$ & FL, 2008-12 & Stansly et al. (2014) \\
\hline $10+$ insecticides & Increase by $\$ 335$ to $\$ 1613$ per acre & $293-556$ & $355-1613$ & $1.2-2.9$ & FL, 2011 & Monzó and Stansly (2015) \\
\hline 13 insecticides & Increase by $13 \%$ to $38 \%$ & $124-403$ & 284-961 & $1.2-3.3$ & FL, 2012-16 & Tansey et al. (2017) \\
\hline Over 30 insecticides & Yield changed from $-27 \%$ to $53 \%$ & $29-717$ & $-602-1292$ & $-3.9-6.2$ & FL, 2010-14 & Monzó and Stansly (2017) \\
\hline 20 insecticides & - & $97-404$ & & & Brazil, 2004-05 & Belasque et al. (2010) \\
\hline Pesticide applications & - & $283-485$ & & & $\mathrm{CA}, 2008$ & Lopez and Durborow (2015) \\
\hline
\end{tabular}

${ }^{\mathrm{z}}$ The results are calculated based on data in the existing studies.

${ }^{\mathrm{y}}$ Costs include materials and labor and are adjusted by annual tree density.

${ }^{\mathrm{x}}$ Prices used in calculating benefits are the annual average on-tree price from USDA-NASS.

${ }^{\mathrm{w}} \mathrm{BCR}$ denotes Benefit-to-Cost Ratio.

activators: SA, oxalic acid, potassium phosphate dibasic, ASM, imidacloprid, L-ascorbic acid sodium salt, $\beta$-aminobutyric acid, and 2,6dichloro-isonicotinic acid (INA), and three antibiotics, including oxytetracycline hydrochloride (OTC), penicillin G sodium salt (PCN), and streptomycin sulfate salt (STM) via trunk injection.

Based on those reported treatment effects, in Table 1 we also show the costs and benefits of the different antibiotic treatments using the application costs described above and the annual average on-tree prices from the USDA-NASS. While penicillin, oxytetracycline, and streptomycin sulfate increase profits by $\$ 339-\$ 664$ per acre, those compounds (particularly when applied using trunk injections) can leave a level of residue in the fruit that poses a risk for human consumption. Penicillin, in particular, which has been found to inhibit the growth of sensitive bacteria by inactivating enzymes located in the bacterial cell membrane (Yang et al., 2015; Zhang et al., 2010, 2014), is unlikely to be approved for use in citrus groves due to its potential impact on human health and the risk that would entail the development of resistant bacteria. The spraying of plant defense regulators (i.e., ascorbic acid, $\beta$-aminobutyric acid, INA, etc.) results in negative profits compared with the untreated control because the increase in revenue is not enough to cover the cost of the treatment.

In 2016, streptomycin sulfate, oxytetracycline hydrochloride, and oxytetracycline calcium complex were approved for use as foliar sprays to treat HLB in Florida (Blaustein et al., 2018) despite the lack of evidence of such application methods being effective in the field; scientific findings that streptomycin and oxytetracycline provided control against HLB were from experiments conducted either in a laboratory setting (Zhang et al., 2014) or using trunk injections (Hu and Wang, 2016). In fact, it has been found that foliar sprays have no positive effect on yield in the field (Li et al., 2019).

Recent studies have suggested that antimicrobial peptides (AMPs) are beneficial in controlling HLB, but their use in the field has been delayed due to their high cost (GuerraLupián et al., 2018; Velasquez Guzman et al., 2018). Choi et al. (2017) proposed that small, synthetic AMPs (usually less than ten amino acids) could be a good alternative because their cost is much lower than that of native AMPs; but this needs further research (Choi et al., 2017).

Insecticides application. Broad-spectrum insecticides have proven to be an effective strategy for reducing ACP populations, especially when targeting overwintering adult populations during tree dormancy (Qureshi and Stansly, 2010). Systemic neonicotinoid insecticides, thiamethoxam, imidacloprid, and clothianidin, as well as cyantraniliprole, are allowed to be used in Florida citrus production (Boina and Bloomquist, 2015) but have some restrictions for their use on young trees (Qureshi et al., 2011, 2014).
Stansly and Roka (2013) reported that after having applied seven insecticides on Valencia orange trees in Florida to control the $\mathrm{ACP}$, the average yield increased by $4 \mathrm{~kg}$ per tree from 2009 to 2012, with an associated cost of $\$ 279$ per acre. Stansly et al. (2014) conducted a 4-year field study and found that the average yield of oranges was $50 \mathrm{~kg}$ per tree with the insecticide treatment compared with $44 \mathrm{~kg}$ per tree without it. The cost associated with the insecticide applications was about \$99-\$278 per acre. Monzó and Stansly (2015) showed that insecticide treatments targeting ACP in citrus orchards led to higher revenue (about $\$ 985$ per acre) and costs (up to $\$ 424$ per acre). Similarly, Tansey et al. (2017) applied 13 different insecticides and found that the average yield in the treatment group was $80 \mathrm{~kg}$ per tree, which was $20 \%$ (13 kg per tree) higher than yield in the untreated group $(67 \mathrm{~kg})$; they reported that the associated cost for insecticide applications was about \$254 per acre. Monzó and Stansly (2017) tested 30 insecticides and found the yield improvement was insignificant (42-kg solids per acre on average), but that cost could increase by $\$ 607$ per acre. Studies beyond Florida also showed similar results in terms of the cost of using insecticides. For example, in Brazil, the cost was estimated at \$97-\$404 per acre (Belasque et al., 2010) and in California, \$283-\$485 per acre (Lopez and Durborow, 2015).

Table 2 presents the impact of using insecticides for HLB control based on the results reported in the cited studies. The yield 
change ranged from $-27 \%$ to $53 \%$, resulting in revenue ranging from $-\$ 602$ to $\$ 1292$ per acre when using the USDA-NASS annual average on-tree price, while the cost ranged from \$29 to \$717 per acre. Overall, the BCR of using insecticides across studies is from -3.9 to 6.2 .

While the use of insecticides has been shown to have a significant impact on citrus fruit yield when psyllid infestation rates are high, intensive insecticide use can result in resistance in ACP populations and also can increase the probability of secondary pest outbreaks (Tansey et al., 2017). For instance, Chen et al. (2018) reported the evidence of psyllid field populations showing moderate to high levels of resistance for thiamethoxam.

The use of economic thresholds for applying insecticides is an important Integrated Pest Mangement practice to limit the probability of the development of resistance and the outbreak of secondary pests. Monzó and Stansly (2017) compared the impact of two economic thresholds for the use of insecticide applications to control ACP: 0.2 and 0.7 psyllids/stem tap samples. Yield increase was observed for samples treated by 0.2 psyllids/stem taps, but there was no significant effect in the case of 0.7 psyllids/stem taps.

Enhanced foliar nutritionals programs. Many growers have implemented enhanced foliar nutritional programs in their groves (Gottwald et al., 2012; Stansly et al., 2014). Some studies indicate that foliar nutritional programs can contribute to maintaining the productivity of infected trees by mitigating the nutritional deficiencies caused by HLB (Ozores-Hampton et al., 2017; Rouse et al., 2017). Nutrients such as N, K, Mn, Zn, B, and $\mathrm{Mg}$ are widely used for growth and increase the productivity of citrus trees infected with CLas (Morgan et al., 2016). Applications of macro-nutrients $(\mathrm{N}, \mathrm{P}$, and $\mathrm{K}$ salts) and micronutrients (primarily $\mathrm{B}, \mathrm{Mg}$, and $\mathrm{Zn}$ salts) may allow foliage to acquire essential elements that might be limited by root dys- function. Stansly et al. (2014) reported increased productivity of HLB-affected Valencia orange trees after receiving foliar nutritional sprays.

The use of enhanced foliar nutritional treatments, however, has also been criticized. The cost of foliar nutritional treatments might be greater than the added value of higher yield (Gottwald et al., 2012; Tansey et al., 2017). Morgan et al. (2016) found that yield was most strongly affected by the application of $\mathrm{MnSO}_{4}$, but the average yield of the 3-year treatment was slightly higher than that of the unsprayed control. Rouse et al. (2017) evaluated the effects of enhanced foliar nutritional treatments by spraying a mixture of micronutrients, macronutrients, potassium nitrate $\left(\mathrm{KNO}_{3}\right)$, and micronutrient package KNO3 and urea. They found that enhanced foliar nutritional treatments can improve early yield. Stansly and Roka (2013) applied enhanced foliar nutritionals to mitigate the debilitating effects of the disease. The isolated effect of foliar nutrition on the yield was negative $(-4 \%)$, at a total cost of $\$ 643$ per acre. The BCR averaged across studies was -0.2 , implying it is an inefficient treatment. Using a mixture consisting primarily of micronutrients and macronutrients, Stansly et al. (2014) found that the yield changed from $-24 \%$ to $23 \%$, with an increased cost of $\$ 729$ per acre and an average BCR of 0.4 . Ozores-Hampton et al. (2017) demonstrated that the nutritional treatments did not have bactericidal effects on the bacterial pathogen $C$ Las and only slightly increased the yield by $7 \%$ to $9 \%$. Comparatively, the cost of the micronutrient package KNO3 and urea was $\$ 343$ per acre on average. Table 3 shows the reported effects of enhanced foliar nutritional programs on crop yield along with their associated costs. Most studies show that foliar nutritional treatments are not economically cost-effective.

Thermotherapy. Thermotherapy treatment has been proposed to manage $C$ Las and suppress phytopathogen titers (Yang et al., 2016). Hoffman et al. (2013) found that the titer of $C$ Las dropped by more than 40 -fold in grapefruit when under $40{ }^{\circ} \mathrm{C}$ for $24 \mathrm{~h}$ or $42^{\circ} \mathrm{C}$ for $19 \mathrm{~h}$ for 2 consecutive days. Zhang et al. (2016) reported that exposing HLB-infected Ray Ruby seedlings to $45^{\circ} \mathrm{C}$ for $8 \mathrm{~h}$ per day for 1 week resulted in significant decreases in phytopathogen titer. Similarly, Fan et al. (2016) showed that if seedlings were exposed to 45 or $48^{\circ} \mathrm{C}$ for $4 \mathrm{~h}$ on $1 \mathrm{~d}$ per week for 3 consecutive weeks, the titer of $C$ Las within leaves declined by about $30 \%$ and $55 \%$, respectively, although it might have caused severe plant tissue damage.

A major challenge with thermotherapy, however, is that it is difficult to perform field treatments. The critical temperature and duration to kill $C$ Las are still unclear (Ehsani and Pertiwi, 2015; Jia et al., 2017). High temperatures may injure the canopy (Fan et al., 2016); and, more importantly, the root system likely escapes the imposed heat treatment, and the heat will likely not penetrate enough into the thick portion of the bark on the trunk, thus providing inoculum to reinfect the canopy (Chalak et al., 2005). The efficacy of thermotherapy depends on both the aboveground and belowground components of the plant being properly treated (Blaustein et al., 2018). As Yang et al. (2016) demonstrated, combined with antimicrobial compounds, thermotherapy enhanced the delivery efficiency of chemical formulations into the citrus phloem.

Existing studies have discussed the impact of thermotherapy treatments on fruit yield and fruit quality under various temperatures and timings. Al-Jumaili and Ehsani (2015) found that when the surrounding air temperature was increased up to 55 to $65^{\circ} \mathrm{C}$ for about 1 to $2 \mathrm{~min}$, the initial results in some samples showed significant changes in juice quality. Longer heating durations resulted in higher brix, but the effects weakened at higher temperatures. Although the acidity of the juice was unaffected by heat treatments, the brix:acid ratio increased significantly at a

Table 3. Impact of foliar nutritional programs on fruit yield and profit.

\begin{tabular}{|c|c|c|c|c|c|c|}
\hline Treatment & Impact on yield ${ }^{\mathrm{z}}$ & $\operatorname{Cost}(\$)^{y}$ & Benefit $(\$)^{x}$ & $\mathrm{BCR}^{\mathrm{w}}$ & Location & Reference \\
\hline$\overline{\mathrm{N}}, \mathrm{K}, \mathrm{Mn}, \mathrm{Zn}, \mathrm{B}$, and $\mathrm{Mg}$ & $\begin{array}{l}\text { Yield was } 45 \% \text { higher in the } 3 \times / \text { year } \\
\text { treatment of } \mathrm{N} \text { and } \mathrm{K} \text {, but declined } \\
\text { by } 25 \% \text { for the } 6 \times / \text { year treatment } \\
\text { of } \mathrm{N} \text { and } \mathrm{K} \text {. Yield decreased by } 25 \% \\
\text { from using } \mathrm{Mn} \text {; there is no significant } \\
\text { impact on yield using B and } \mathrm{Mg} \text {. }\end{array}$ & - & - & - & FL, 2010-14 & Morgan et al. (2016) \\
\hline $\begin{array}{l}\text { Micronutrient to package } \\
\text { [potassium nitrate } \\
\left(\mathrm{KNO}_{3}\right) \text { and urea] }\end{array}$ & $\begin{array}{l}\text { Enhanced foliar nutritional treatments } \\
\text { provide some yield benefits, especially } \\
\text { in the early years of the trial. }\end{array}$ & - & - & - & FL, 2010-14 & Rouse et al. (2017) \\
\hline $\begin{array}{l}\text { Enhanced nutritional programs } \\
\qquad(\mathrm{K}, \mathrm{Mn}, \mathrm{Zn}, \mathrm{Cu} \text {, and PDS })\end{array}$ & $\begin{array}{l}\text { ENP might increase disease spread } \\
\text { within and between citrus orchards. }\end{array}$ & $\$ 729.6$ & $\$ 617.1$ & 0.8 & FL, 2009-10 & Gottwald et al. (2012) \\
\hline Enhanced foliar nutrition & $\begin{array}{l}\text { Yield was } 4 \% \text { lower than the control } \\
\text { group. }\end{array}$ & $\$ 643.0$ & -139.8 & -0.2 & FL, 2009-12 & $\begin{array}{l}\text { Stansly and Roka } \\
\text { (2013) }\end{array}$ \\
\hline $\begin{array}{l}\text { A mixture consisting primarily } \\
\text { of micro- and macro-nutrients }\end{array}$ & Yield changed from $-24 \%$ to $23 \%$. & $\$ 729.4$ & $\$ 7.41$ & 0.4 & FL, 2009-12 & Stansly et al. (2014) \\
\hline $\begin{array}{l}\text { K-phite, Saver, Mg, Mn, Zn, Mo, } \\
\text { K, } 435 \text { Oil }\end{array}$ & Yield increased by $7 \%$ to $9 \%$. & $\$ 343.3$ & $\$ 443.4$ & 1.3 & FL, 2011-15 & $\begin{array}{l}\text { Ozores-Hampton et al } \\
\quad(2017)\end{array}$ \\
\hline
\end{tabular}

${ }^{\mathrm{z}}$ The results are calculated based on data in the existing studies.

${ }^{\mathrm{y}}$ Costs include materials and labor and are adjusted by annual tree density.

${ }^{\mathrm{x}}$ Prices used in calculating benefits are the annual average on-tree price from USDA-NASS.

${ }^{\mathrm{w}} \mathrm{BCR}$ denotes Benefit-to-Cost Ratio. 
Table 4. Impact of thermotherapy treatments on fruit yield and profit.

\begin{tabular}{|c|c|c|c|c|c|c|}
\hline Treatment & Impact on yield ${ }^{2}$ & $\operatorname{Cost}(\$)^{y}$ & Benefit $(\$)^{x}$ & $\mathrm{BCR}^{\mathrm{w}}$ & Location & Reference \\
\hline $\begin{array}{c}140^{\circ} \mathrm{F} \text { for } 30 \mathrm{~s} \text { and } \\
131^{\circ} \mathrm{F} \text { for } 120 \mathrm{~s}\end{array}$ & $\begin{array}{l}\text { Heat treatment had an adverse effect } \\
\text { on yield in the first year }(1 \% \text { to } 6 \%) \text {. } \\
\text { Yield reduction was greater in trees } \\
\text { treated at a higher temperature. }\end{array}$ & & -1227.8 & -2.4 & FL, 2015 & Ehsani et al. (2016) \\
\hline $\begin{array}{l}55 \text { to } 65^{\circ} \mathrm{C} \\
\text { for } 1-2 \mathrm{~min}\end{array}$ & $\begin{array}{l}\text { Higher brix; no impact on the } \\
\text { acidity; brix/acid ratio increased at a } \\
\text { higher temperature or longer duration. }\end{array}$ & & - & - & FL, 2014 & Al-Jumaili and Ehsani (2015) \\
\hline $55^{\circ} \mathrm{C}$ for $1 \mathrm{~h}$ & $\begin{array}{l}\text { Mean yield was significantly higher } \\
\text { than the yield of HLB-affected } \\
\text { trees that were not treated. }\end{array}$ & & - & - & FL, 2015 & Ehsani and Pertiwi (2015) \\
\hline $131^{\circ} \mathrm{F}$ for $30 \mathrm{~s}$ & $\begin{array}{l}\text { Fixed cost of the improved thermotherapy } \\
\text { system totaled } \$ 54,845 \text {; the variable } \\
\text { cost per tree was } \$ 2.40 \text { on average, and } \\
\$ 6.50 \text { to } \$ 7.50 \text { for the total. }\end{array}$ & & - & - & FL, 2015 & Trotochaud and Ehsani (2016) \\
\hline
\end{tabular}

Table 5. Biological control of vector population.

\begin{tabular}{lcc}
\hline Treatment & \multicolumn{1}{c}{ Conclusion } & Reference \\
\hline Biological control & Achieving economic efficiency is one of the & Bolckmans (2007) \\
& greatest challenges of biological control. & \\
T. radiata & $\$ 0.05$ in Brazil & Alvarez et al. (2016) \\
T. radiata & The total annual costs for operation of the & Parra et al. (2016) \\
& program are estimated at \$361,529 & \\
& to produce 3.3 million wasps at the & \\
cost of about $\$ 0.11$ per parasitoid, & Trivedi et al. (2010) \\
Bradyrhizobium and & or $\$ 9.79$ per hectare. & \\
\hline
\end{tabular}

higher temperature or a longer duration. Ehsani et al. (2013) developed a prototype of a mobile system that used solar radiation to heat-treat HLB-infected trees in an orange grove. Valencia trees were covered with translucent plastic for a 5 -hour heating period that reached $45^{\circ} \mathrm{C}$. The results indicated that treated trees in midsummer had higher yields $(30 \%)$ than controlled trees. The subsequent study by Ehsani and Pertiwi (2015) found that a treatment of $55^{\circ} \mathrm{C}$ for $1 \mathrm{~h}$ produced a significantly higher yield than nontreated trees. However, the latest study by Ehsani et al. (2016) suggested that heat treatments had adverse effects on the yield in the first year due to heat-induced fruit drop. Yield reduction was greater $(1 \%$ to $6 \%)$ in trees that were treated at a higher temperature. The results are consistent with a recent study by Dewdney et al. (2018), who concluded that thermotherapy does not improve yield enough to compensate for the damage caused to the canopy. Treatment results of various temperatures and timings are illustrated in Table 4.

The cost of thermotherapy for controlling HLB is reported only by Trotochaud and Ehsani (2016). The estimated fixed cost of the improved thermotherapy system included mobile platform $(\$ 15,000)$, steam generator
$(\$ 20,000)$, water storage (\$285), water pump $(\$ 1000)$, water filter $(\$ 60)$, water softener $(\$ 2300)$, electricity generator $(\$ 600)$, tree enclosure $(\$ 15,000)$, and electronics $(\$ 600)$, for a total of $\$ 54,845$. The variable cost for operation primarily consisted of labor and fuel, which is $\$ 2.40$ per tree on average. The total cost was $\$ 6.50-\$ 7.50$ per tree if renting a machine. Overall, heat treatment had an adverse effect on yield. The estimated benefits from thermotherapy ranged from $-\$ 1788.2$ to $\$ 811.8$, with a BCR of -1.9 to 0.87 (Table 4).

Biological control. Vector control is considered an essential component of HLB management even in an environment with high disease incidence. Implementing biological control, or combining it with other disease management strategies, such as use of organic amendments, tolerant/resistant cultivars, or pathogen-free certified planting material, may be feasible (Alvarez et al., 2016; Cazorla and Mercado-Blanco, 2016). Tamarixia radiata was found to be an effective biocontrol agent against ACP (Chen et al., 2017). T. radiata was introduced in Florida, and its control effect on ACP populations is reported to range between $4 \%$ and $70 \%$ (Gottwald et al., 2007). The convergent lady beetle, Hippodamia convergens Guérin-Méneville, has been released in
Florida, but it is still not commonly used as a biocontrol agent in citrus groves (Qureshi and Stansly, 2011).

A few studies have discussed the cost of parasitoids used for psyllid control (Table 5). Parra et al. (2016) estimated the cost of the biological-control approach in Brazil and found the cost (including all costs involved in the rearing process) was $\$ 0.05$ per parasitoid, or $\$ 9.71$ per acre. In contrast, the cost in Florida was much higher at $\$ 0.11$ per parasitoid (Alvarez et al., 2016). To date, no studies have shown the effect of biological control on yield, so its cost effectiveness is not evaluated in this study.

Other treatments. Despite ongoing efforts made by growers to modify their citrus production practices to control HLB, the phytopathogen has spread to infect most citrus groves (Martinelli et al., 2016; Plotto et al., 2017; Rouse et al., 2017). Other proposed treatments for coping with HLB include tree removal and pruning, interplanting crops, and transgenic biotechnology.

According to some scientists, tree removal and pruning are the most effective treatment for controlling ACP populations (Gottwald, 2010), but this approach is not cost efficient and is difficult to implement in practice because it needs coordinated efforts from neighboring growers (Table 6). For example, Muraro (2010) estimated the increased grove maintenance costs for eradicating infected trees at about $\$ 450$ per acre. Roka et al. (2010) reported that the per-acre cost increase in grove maintenance associated with tree replacement ranges from $\$ 200$ to $\$ 600$ per acre. Moreover, the study by Ozores-Hampton et al. (2017) found that although yields from pruned trees were higher than yields from nonpruned trees, the total cost of pruning was estimated to be $\$ 160$ per acre.

Other scientists have suggested that infestations of psyllids in citrus can be reduced 
when citrus is interplanted with guava (Ahmed et al., 2013; Tsai et al., 2013), which apparently inhibits the psyllid vector (Beattie et al., 2006). Gottwald et al. (2014) found a significant reduction in Asian citrus psyllid infestation in citrus interplanted with pink guava, but there was no reduction in Asian citrus psyllid infestation when citrus was interplanted with white guava. However, interplanted citrus with either white or pink guava did not prevent the introduction and spread of HLB.

A potential long-term solution to HLB is the development of transgenic citrus. One such proposal intends to develop a citrus variety that overexpresses the Arabidopsis thaliana NPR1 gene to regulate systemic acquired resistance (Dutt et al., 2015). Overexpression of modified plant thionins with antimicrobial activity has also been reported to enhance HLB resistance (Hao et al., 2016).

Table 6. Other treatments for controlling HLB.

\begin{tabular}{|c|c|c|}
\hline Treatment & Conclusion & Reference \\
\hline \multirow{3}{*}{$\begin{array}{l}\text { Tree removal and } \\
\text { pruning }\end{array}$} & Grove maintenance costs are about $\$ 450$ per acre. & Muraro (2010) \\
\hline & Replacement cost is $\$ 200-\$ 600$ per acre. & Roka et al. (2010) \\
\hline & Tree removal is $\$ 566-\$ 680$ per acre. & Monzó and Stansly (2017) \\
\hline \multirow[t]{2}{*}{ Interplanting } & $\$ 1-\$ 3$ per tree in Brazil & Belasque et al. (2010) \\
\hline & $\begin{array}{l}\text { Yield in interplanted orchards is higher } \\
\text { than in noninterplanted orchards. }\end{array}$ & Gottwald (2010) \\
\hline $\begin{array}{l}\text { Transgenic } \\
\text { biotechnology }\end{array}$ & Induces effects on target insects but is costly & Hajeri et al. (2014) \\
\hline
\end{tabular}

While gene-editing tools, such as the CRISPRCas9, are being researched to create citrus cultivars that are less susceptible to CLas or to express genes that may prevent vector transmission, transgenic biotechnology is costly (Wang et al., 2017; Zhang et al., 2017). It is also important to consider that the adoption of biotechnology on citrus will very likely present challenges in the marketplace because some consumers are strongly averse to it.

\section{Economic Performance of Treatments}

Figure 2 illustrates the range for costs, benefits, profits, and BCRs associated with able in the studies reviewed (Tables 1-4). The number of observations analyzed for antibiotics, insecticides, foliar nutritional programs, and thermotherapy are 74,38 , 26 , and 80 , respectively. each type of treatment based on data avail-
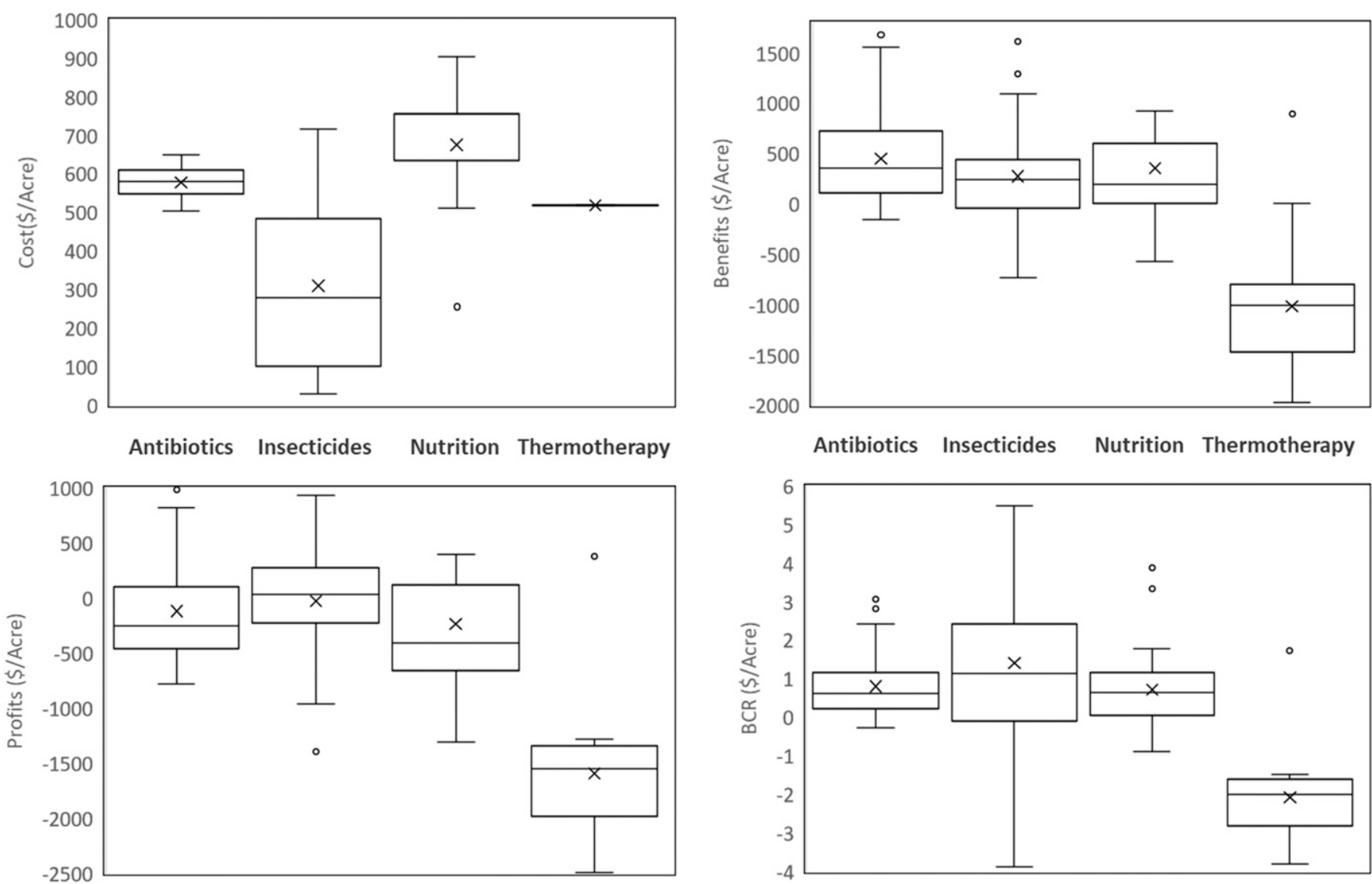

Antibiotics Insecticides Nutrition Thermotherapy

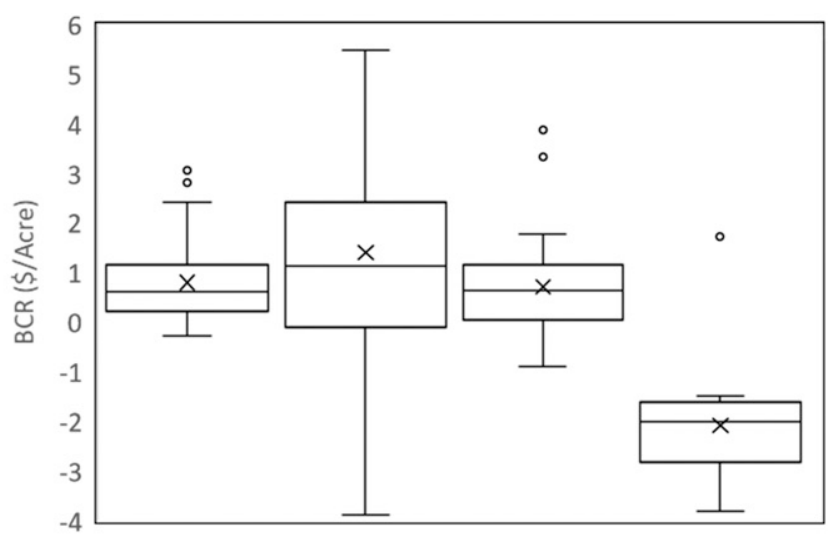

Fig. 2. Comparison of benefits and costs of the proposed treatments against HLB. The results are estimated based on data available in the studies reviewed. Superscript dots are the outliers of the results in each treatment. The number of observations for antibiotics, insecticides, foliar nutritional programs, and thermotherapy are $74,38,26$, and 80 , respectively. 
Table 7. $t$ test for the measurements between treatments. ${ }^{2}$

\begin{tabular}{|c|c|c|c|c|}
\hline & & Antibiotic & Insecticide & Foliar nutritionals \\
\hline \multirow[t]{4}{*}{ Cost } & Antibiotic & - & - & - \\
\hline & Insecticide & $2.86^{* *}$ & - & - \\
\hline & Foliar nutritionals & 1.36 & 1.21 & - \\
\hline & Thermotherapy & $11.75 * * *$ & $9.71 * * *$ & $10.50 * * *$ \\
\hline \multirow[t]{4}{*}{ Benefit } & Antibiotic & - & - & - \\
\hline & Insecticide & 7.40 & - & - \\
\hline & Foliar nutritionals & $3.68 * *$ & $6.62 * * *$ & - \\
\hline & Thermotherapy & $6.29 * * *$ & $8.23 * * *$ & $15.46^{* * *}$ \\
\hline \multirow[t]{4}{*}{ Profit } & Antibiotic & - & - & - \\
\hline & Insecticide & 0.11 & - & - \\
\hline & Foliar nutritionals & 1.58 & 0.68 & - \\
\hline & Thermotherapy & $10.60 * * *$ & $0.68 * * *$ & $5.97 * * *$ \\
\hline \multirow[t]{4}{*}{ BCR } & Antibiotic & - & - & - \\
\hline & Insecticide & 1.05 & - & - \\
\hline & Foliar nutritionals & 1.39 & 1.28 & - \\
\hline & Thermotherapy & $10.90 * * *$ & $5.73 * * *$ & $7.28 * * *$ \\
\hline
\end{tabular}

${ }^{\mathrm{z}}$ The reported values are the $t$-static between two treatments; Ho: mean(diff) $=0 ; * * P<0.05, * * * P<0.01$.

nutritionals are estimated at $-\$ 251, \$ 28$, and -\$411 per acre, respectively. Because there was no positive yield effect when using thermotherapy, the treatment is not economically feasible. The median values of the BCR for antibiotics, insecticides, foliar nutritionals, and thermotherapy are $0.60,1.12$, 0.63 , and -1.99 , respectively. BCR values smaller than one imply that the cost outweighs the benefit.

In Table 7 we report the results of a test on whether the means are statistically different for the treatments in each of the measurements in Fig. 2. The results show that for any two comparisons of antibiotics, insecticides, or foliar nutritional programs, the means for profits or BCR are not statistically different. However, the means for cost, benefit, profit, and BCR for thermotherapy were statistically different from any of the other three treatments. The application of antibiotics and insecticides resulted in significant differences in terms of costs and benefits, but profits and BCR were not statistically different. Antibiotics and foliar nutritionals, as well as foliar nutritionals and insecticides, were only statistically different in terms of benefits.

Biological control is an inexpensive strategy, but there are no data on how it affects yield (Al-Jumaili and Ehsani, 2015; Lin et al., 2010). Also, while it has been found that the spread of disease might be contained by removing infected trees (Warnert, 2012), the cost of such practice is relatively high, and the economic losses derived from yield reduction due to tree removal are even larger. However, high-density plantings have been found to be a profitable strategy to mitigate the impact of HLB (Singerman et al., 2018). A treatment that has been recently incorporated by citrus growers in Florida (and for which there is still no data) is referred to as "nutritional spoon-feeding"; this basically involves providing trees with high frequency but low doses of fertilizer. Some scientists are testing growing citrus trees under enclosed structures to prevent HLB infection (Ferrarezi et al., 2019; Schumann et al., 2019). While such a strategy has a high establishment cost, preliminary results show it is profitable for growing fresh fruit
(Schumann et al., 2019). Growers and researchers are testing individual protective covers to protect young citrus trees from becoming infected with HLB. Finally, disease-resistant or tolerant varieties have also been proposed as a long-term solution to the disease; but without data on this solution's impact on yield, its cost-effectiveness cannot be investigated.

\section{Conclusions and Discussion}

The outbreak of HLB has significantly impacted the citrus industry, particularly in Florida but also in Brazil (the world's largest orange producer). Recently, the disease has started to spread throughout California. While there is still no cure for HLB, scientists have proposed different treatments to manage the disease. Thus, in this study we reviewed some of the major treatments that have been proposed, and we found that their profitability varies widely. We found that broad-spectrum insecticides provide the only cost-effective strategy for mitigating the impact of the disease. Citrus-growing regions in which the spread of the disease is incipient can use the lessons learned in Florida to be more effective in coping with HLB and to avoid a similar outcome. In addition, the combination of treatments such as nutrients and antibiotics (Zhang et al., 2019), insecticide and foliar nutrients (Tansey et al., 2017), and biological control with chemicals (Kumar et al., 2017) have been conducted in recent studies and were found to have complementary effects and a better performance on control of the ACP and yield increment. Whether those combinations of treatments are cost-effective could be addressed in future studies.

While individual applications of synthetic pesticides have allowed growers to manage many pests effectively and cheaply (Smith et al., 1976), there are, however, some caveats to be noted with respect to their intensive use. Using site-specific sprays is not optimal when managing invasive species because the effectiveness of individual uncoordinated pest control is compromised by the mobility of pests (Vreysen et al., 2007).
Therefore, growers' ability to control the ACP and HLB depends on the actions of neighboring growers (Singerman et al., 2017). Government top-down regulation or a collective action can help growers coordinate their efforts and be more effective (Singerman and Rogers, 2020). Another important aspect to consider is that the intensive use of pesticides has an additional cost to that included in their market price; those costs include potential ecological harm, excessive chemical residue in the fruit, and the development of resistance. Therefore, cooperation among neighboring growers for the control of the ACP-for example, through an area-wide spraying program - can not only be more effective, but also contribute to lessening those additional costs, making society as a whole better off.

It is worth noting that besides the threat posed by HLB, there are also other challenges that affect the entire specialty crop industry, including intensifying foreign competition (Suh et al., 2017; Wu et al., 2018a, 2018b) and labor shortages (Cao et al., 2019; Wu et al., 2015), which add further concerns to the industry's economic outlook. For example, recent data from the USDA-ERS show that Mexico's exports of orange juice to the United States have increased dramatically in the last few years, and this trend is expected to continue. Coordinated actions and policies are needed to address these threats to the industry to ensure its long-term sustainability.

\section{Literature Cited}

Aćimović, S.G., Q. Zeng, G.C. McGhee, G.W. Sundin, and J.C. Wise. 2015. Control of fire blight (Erwinia amylovora) on apple trees with trunk-injected plant resistance inducers and antibiotics and assessment of induction of pathogenesis-related protein genes. Front. Plant Sci. 6:16.

Ahmed, S., M.A. Khan, and M. Qasam. 2013. Effect of intercropping of maize in citrus orchards on citrus leaf miner infestation and population of its natural enemies. Pak. J. Agr. Sci. 50:91-93.

Aldeek, F., D. Canzani, M. Standland, M.R. Crosswhite, W. Hammack, G. Gerard, and J.-M. Cook. 2016. Identification of penicillin $\mathrm{G}$ metabolites under various environmental conditions using UHPLC-MS/MS. J. Agr. Food Chem. 64:6100-6107.

Aldeek, F., M.R. Rosana, Z.K. Hamilton, M.R. Crosswhite, C.W. Burrows, S. Singh, G. Gerard, W. Hammack, and J.-M. Cook. 2015. LC-MS/MS method for the determination and quantitation of penicillin $\mathrm{G}$ and its metabolites in citrus fruits affected by huanglongbing. J. Agr. Food Chem. 63:5993-6000.

Al-Jumaili, A. and R. Ehsani. 2015. Mobile batch heat treatment system for treating HLBinfected citrus trees. 2015 ASABE Annu. Intl. Meet. 1.

Alvarez, S., E. Rohrig, D. Solís, and M.H. Thomas. 2016. Citrus greening disease (huanglongbing) in Florida: Economic impact, management and the potential for biological control. Agr. Res. 5:109-118.

Beattie, G.A.C., P. Holford, D.J. Mabberley, A.M. Haigh, R. Bayer, and P. Broadbent. 2006. Aspects and insights of Australia-Asia 
collaborative research on huanglongbing. The International Workshop for the Prevention of Citrus Greening Disease in Severely Infested Areas. Tokyo, 7-9 Dec. 2006.

Belasque, J., Jr., R.B. Bassanezi, P.T. Yamamoto, A.J. Ayres, A. Tachibana, A.R. Violante, A. Tank, Jr., F. Di Giorgi, F.E.A. Tersi, and G.M. Menezes. 2010. Lessons from huanglongbing management in São Paulo state, Brazil. J. Plant Pathol. 92:285-302.

Blaustein, R.A., G.L. Lorca, and M. Teplitski. 2018. Challenges for managing Candidatus Liberibacter spp. (huanglongbing disease pathogen): Current control measures and future directions. Phytopathology 108:424-435.

Boina, D.R. and J.R. Bloomquist. 2015. Chemical control of the Asian citrus psyllid and of huanglongbing disease in citrus. Pest Manag. Sci. 71:808-823.

Bolckmans, K.J.F. 2007. Reliability, quality and cost: The basic challenges of commercial natural enemy production. Proceedings 11 th Meet. Work. Group Arthropod Mass Rearing Qual. Control 28:8-11.

Cao, X., Z. Guan, G.E. Vallad, and F. Wu. 2019. Economics of fumigation in tomato production: The impact of methyl bromide phase-out on the Florida tomato industry. Int. Food Agribus. Manag. Rev. 22:589-600.

Cazorla, F.M. and J. Mercado-Blanco. 2016. Biological control of tree and woody plant diseases: An impossible task? BioControl 61:233-242.

Chalak, L., A. Elbitar, R. Rizk, E. Choueiri, P. Salar, and J.M. Bové. 2005. Attempts to eliminate Candidatus Phytoplasma phoenicium from infected Lebanese almond varieties by tissue culture techniques combined or not with thermotherapy. Eur. J. Plant Pathol. 112:85-89.

Chen, X., M. Triana, and P.A. Stansly. 2017. Optimizing production of Tamarixia radiata (Hymenoptera: Eulophidae), a parasitoid of the citrus greening disease vector Diaphorina citri (Hemiptera: Psylloidea). Biol. Control 105:13-18.

Chen, X.D., T.A. Gill, M. Ashfaq, K.S. Pelz-Stelinski, and L.L. Stelinski. 2018. Resistance to commonly used insecticides in Asian citrus psyllid: Stability and relationship to gene expression. J. Appl. Entomol. 142:967-977.

Choi, J., E. Park, S.-W. Lee, J.-W. Hyun, and K.-H. Baek. 2017. Selection of small synthetic antimicrobial peptides inhibiting Xanthomonas citri subsp. citri causing citrus canker. Plant Pathol. J. 33:87.

Court, C.D., A.W. Hodges, M. Rahmani, and T.H. Spreen. 2017. Economic contributions of the Florida citrus industry in 2015-16. FE1021. UF/IFAS Extension, Gainesville, FL. <https:// fred.ifas.uff.edu/pdf/economic-impact-analysis/ Economic_Impacts_of_the_Florida_Citrus_Industry_ 2015_16.pdfs.

Dewdney, M., E. Johnson, N. Thapa, and M. Danyluk. 2018. Thermotherapy's effects on fruit drop, yield and quality. Citrus Industry News. Dec.: 12-15.

Dixon, W., R. Gaskalla, X. Sun, and G. Hodges. 2014. Progress of an antimicrobial treatment for huanglongbing: The Florida Citrus Arboretum. <https://citrusagents.ifas.ufl.edu/events/ GrowersInstitute2015/pdf/Dixon.pdfs.

Dutt, M., G. Barthe, M. Irey, and J. Grosser. 2015. Transgenic citrus expressing an Arabidopsis NPR1 gene exhibit enhanced resistance against Huanglongbing (HLB; citrus greening). PLoS One 10:e0137134.

Ehsani, R., J.I.R. De Corcuera, and L. Khot. 2013. The potential of thermotherapy in combatting HLB. Resour. Mag. 20:18-19.
Ehsani, R., M. Dewdney, and E. Johnson. 2016. Controlling HLB with thermotherapy: What have we learned so far? Citrus Industry News. Sept.:26-28.

Ehsani, R. and C. Pertiwi. 2015. Tenting and supplementary heat for thermotherapy of HLB trees. Citrus Industry News Aug.:8-12.

Fan, G., Y. Xia, X. Lin, H. Hu, X. Wang, C. Ruan, L. $\mathrm{Lu}$, and L. Bo. 2016. Evaluation of thermotherapy against huanglongbing (citrus greening) in the greenhouse. J. Integr. Agr. 15:111-119.

Ferrarezi, R.S., J.A. Qureshi, A.L. Wright, M.A. Ritenour, and N.P. Macan. 2019. Citrus production under screen as a strategy to protect grapefruit trees from huanglongbing disease. Front. Plant Sci. 10:1598.

Gottwald, T.R. 2010. Current epidemiological understanding of citrus huanglongbing. Annu. Rev. Phytopathol. 48:119-139.

Gottwald, T.R., J.V. da Graça, and R.B. Bassanezi. 2007. Citrus huanglongbing: The pathogen and its impact. Plant Health Prog. 6:1-18.

Gottwald, T.R., J.H. Graham, M.S. Irey, T.G. McCollum, and B.W. Wood. 2012. Inconsequential effect of nutritional treatments on huanglongbing control, fruit quality, bacterial titer and disease progress. Crop Prot. 36:73-82.

Gottwald, T.R., D.G. Hall, A.B. Kriss, E.J. Salinas, P.E. Parker, G.A.C. Beattie, and M.C. Nguyen. 2014. Orchard and nursery dynamics of the effect of interplanting citrus with guava for huanglongbing, vector, and disease management. Crop Prot. 64:93-103.

Grafton-Cardwell, E.E., L.L. Stelinski, and P.A. Stansly. 2013. Biology and management of Asian citrus psyllid, vector of the huanglongbing pathogens. Annu. Rev. Entomol. 58:413432.

Guerra-Lupián, M.-A., R. Ruiz-Medrano, J.-A. Ramírez-Pool, F.-A. Ramírez-Ortega, J.-A. López-Buenfil, E. Loeza-Kuk, O. MoralesGalván, C. Chavarin-Palacio, J. Hinojosa-Moya, and B. Xoconostle-Cázares. 2018. Localized expression of antimicrobial proteins mitigates huanglongbing symptoms in Mexican lime. J. Biotechnol. 285:74-83.

Hajeri, S., N. Killiny, C. El-Mohtar, W.O. Dawson, and S. Gowda. 2014. Citrus tristeza virus-based RNAi in citrus plants induces gene silencing in Diaphorina citri, a phloem-sap sucking insect vector of citrus greening disease (huanglongbing). J. Biotechnol. 176:42-49.

Hao, G., E. Stover, and G. Gupta. 2016. Overexpression of a modified plant thionin enhances disease resistance to citrus canker and huanglongbing (HLB). Front. Plant Sci. 7:1078.

Hoffman, M.T., M.S. Doud, L. Williams, M.-Q. Zhang, F. Ding, E. Stover, D. Hall, S. Zhang, L. Jones, and M. Gooch. 2013. Heat treatment eliminates 'Candidatus Liberibacter asiaticus' from infected citrus trees under controlled conditions. Phytopathology 103:15-22.

Hu, J., J. Jiang, and N. Wang. 2017. Control of citrus huanglongbing via trunk injection of plant defense activators and antibiotics. Phytopathology 108(2):186-195.

$\mathrm{Hu}, \mathrm{J}$. and N. Wang. 2016. Evaluation of the spatiotemporal dynamics of oxytetracycline and its control effect against citrus huanglongbing via trunk injection. Phytopathology 106:14951503.

Iftikhar, Y., S. Rauf, U. Shahzad, and M.A. Zahid. 2016. Huanglongbing: Pathogen detection system for integrated disease management-A review. J. Saudi Soc. Agr. Sci. 15:1-11.

Jia, H., Y. Zhang, V. Orbović, J. Xu, F.F. White, J.B. Jones, and N. Wang. 2017. Genome editing of the disease susceptibility gene Cs LOB 1 in citrus confers resistance to citrus canker. Plant Biotechnol. J. 15:817-823.

Kumar, V., P.B. Avery, J. Ahmed, R.D. Cave, C.L. McKenzie, and L.S. Osborne. 2017. Compatibility and efficacy of Isaria fumosorosea with horticultural oils for mitigation of the Asian citrus psyllid, Diaphorina citri (Hemiptera: Liviidae). Insects 8:119.

Li, J., Z. Pang, S. Duan, D. Lee, V. Kolbasov, and N. Wang. 2019. The in planta effective concentration of oxytetracycline against Candidatus Liberibacter asiaticus for suppression of citrus huanglongbing. Phytopathology 109:2046-2054.

Li, J., P. Trivedi, and N. Wang. 2015. Field evaluation of plant defense inducers for the control of citrus huanglongbing. Phytopathology 106:37-46.

Lin, H., C. Chen, H. Doddapaneni, Y. Duan, E.L. Civerolo, X. Bai, and X. Zhao. 2010. A new diagnostic system for ultra-sensitive and specific detection and quantification of Candidatus Liberibacter asiaticus, the bacterium associated with citrus huanglongbing. J. Microbiol. Methods 81:17-25.

Lopez, J.A. and S.L. Durborow. 2015. Huanglongbing and the California citrus industry: A cost comparison of do nothing vs. do something management practices. Tex. J. Agr. Nat. Resour. 27:51-68.

Martinelli, F., D. Dolan, V. Fileccia, R.L. Reagan, M. Phu, T.M. Spann, T.G. McCollum, and A.M. Dandekar. 2016. Molecular responses to small regulating molecules against huanglongbing disease. PLoS One 11:e0159610.

Martini, X., K.S. Pelz-Stelinski, and L.L. Stelinski. 2015. Absence of windbreaks and replanting citrus in solid sets increase density of Asian citrus psyllid populations. Agr. Ecosyst. Environ. 212:168-174.

Monzó, C. and P.A. Stansly. 2015. Thresholds for vector control and compatibility with beneficial fauna in citrus with high incidence of huanglongbing. Acta Hort. 1065:1137-1144.

Monzo, C. and P.A. Stansly. 2017. Economic injury levels for Asian citrus psyllid control in process oranges from mature trees with high incidence of huanglongbing. PLoS One 12 :e0175333.

Morgan, K.T., R.E. Rouse, and R.C. Ebel. 2016. Foliar applications of essential nutrients on growth and yield of 'Valencia' sweet orange infected with huanglongbing. HortScience 51: 1482-1493.

Munir, S., P. He, Y. Wu, P. He, S. Khan, M. Huang, W. Cui, P. He, and Y. He. 2017. Huanglongbing control: Perhaps the end of the beginning. Microb. Ecol. 1:1-13.

Muraro, R.P. 2010. Costs of managing HLB and citrus black spot. Presented at Citrus Expo, Ft. Meyers, FL. 19 May 2010.

Ozores-Hampton, M., F.M. Roka, R.E. Rouse, and P. Roberts. 2017. Dual treatment tested for HLB trees. Citrus Industry News. May:28-31.

Parra, J.R.P., G.R. Alves, A.J.F. Diniz, and J.M. Vieira. 2016. Tamarixia radiata (Hymenoptera: Eulophidae) $\times$ Diaphorina citri (Hemiptera: Liviidae): Mass rearing and potential use of the parasitoid in Brazil. J. Integr. Pest Manag. 7:5.

Plotto, A., E. Baldwin, J. Bai, J. Manthey, S. Raithore, S. Deterre, W. Zhao, C. do Nascimento Nunes, P.A. Stansly, and J.A. Tansey. 2017. Effect of vector control and foliar nutrition on the quality of orange juice affected by huanglongbing: Sensory evaluation. HortScience 52:1092-1099.

Puttamuk, T., S. Zhang, Y. Duan, A. Jantasorn, and N. Thaveechai. 2014. Effect of chemical treatments on 'Candidatus Liberibacter asiaticus' infected pomelo (Citrus maxima). Crop Prot. 65:114-121. 
Qureshi, J.A., B.C. Kostyk, and P.A. Stansly. 2014. Insecticidal suppression of Asian citrus psyllid Diaphorina citri (Hemiptera: Liviidae) vector of huanglongbing pathogens. PLoS One 9: E112331.

Qureshi, J.A. and P.A. Stansly. 2010. Dormant season foliar sprays of broad-spectrum insecticides: An effective component of integrated management for Diaphorina citri (Hemiptera: Psyllidae) in citrus orchards. Crop Prot. 29:860-866.

Qureshi, J.A. and P.A. Stansly. 2011. Three homopteran pests of citrus as prey for the convergent lady beetle: Suitability and preference. Environ. Entomol. 40:1503-1510.

Qureshi, O.S., Y. Zheng, K. Nakamura, K. Attridge, C. Manzotti, E.M. Schmidt, J. Baker, L.E. Jeffery, S. Kaur, and Z. Briggs. 2011. Trans-endocytosis of CD80 and CD86: A molecular basis for the cell-extrinsic function of CTLA-4. Science 332:600-603.

Roka, F.R., A.M. Muraro, and A. Morris. 2010. Economics of HLB management: Pull trees or spray nutritionals. Int. Citrus Econ. Conf. Orlando, FL. <https://crec.ifas.ufl.edu/extension/ economics/icec2010/presentations/froka.swf>.

Rouse, R.E., M. Ozores-Hampton, F.M. Roka, and P. Roberts. 2017. Rehabilitation of huanglongbingaffected citrus trees using severe pruning and enhanced foliar nutritional treatments. HortScience 52:972-978.

Schumann, A., A. Singerman, and Y. Wang. 2019. A closer look at CUPS-grown grapefruit: Citrus. Citrus Ind. Mag. Nov. 2019. < http://citrusindustry. net/2019/11/25/a-closer-look-at-cups-growngrapefruit/>.

Shokrollah, H., T. Lee Abdullah, K. Sijam, and S.N.A. Abdullah. 2011. Identification of physical and biochemical characteristic of mandarin (Citrus reticulata) fruit infected by huanglongbing (HLB). Aust. J. Crop Sci. 5:181.

Singerman, A. 2019. Cost of producing processed oranges in southwest Florida in 2018/19. University of Florida, IFAS, CREC, Lake Alfred, FL. $<$ https://crec.ifas.ufl.edu/media/crecifasufledu/ economics/2018_19_SW_Costs_20190816.pdf>.

Singerman, A., M. Burani-Arouca, and S.H. Futch. 2018. The profitability of new citrus plantings in Florida in the era of huanglongbing. HortScience 53:1655-1663.

Singerman, A. and P. Useche. 2017. Florida citrus growers' first impressions on genetically modified trees. AgBioForum 20:67-83.

Singerman, A., S.H. Lence, and P. Useche. 2017. Is area-wide pest management useful? The case of citrus greening. Appl. Econ. Perspect. Policy 39(4):609-634.

Singerman, A. and M.E. Rogers. 2020. The economic challenges of dealing with citrus greening: The case of Florida. J. Integr. Pest Manag. 11:pmz037.

Smith, R.F., J.L. Apple, and D.G. Bottrell. 1976. The origins of integrated pest management concepts for agricultural crops, p. 1-16. In: J.L. Apple and R.F. Smiths (eds.). Integrated pest management. Springer, Boston.
Spann, T.M., A.W. Schumann, B. Rouse, B. Ebel, B. Rouse, and B. Ebel. 2011. Foliar nutrition for HLB. Citrus Ind. 92:6-10.

Stansly, P.A., H.A. Arevalo, J.A. Qureshi, M.M. Jones, K. Hendricks, P.D. Roberts, and F.M. Roka. 2014. Vector control and foliar nutrition to maintain economic sustainability of bearing citrus in Florida groves affected by huanglongbing. Pest Manag. Sci. 70:415-426.

Stansly, P.A. and F.M. Roka. 2013. Economies of HLB vector control and foliar nutrition. Citrus Industry News June:1-2. <https://crec.ifas.ufl. edu/extension/trade_journals/2013/2013_June_ economies.pdf $>$.

Stockwell, V.O. and B. Duffy. 2012. Use of antibiotics in plant agriculture. Rev. Sci. Tech. 31(1):199-210.

Suh, D.H., Z. Guan, and H. Khachatryan. 2017. The impact of Mexican competition on the US strawberry industry. Int. Food Agribus. Manag. Rev. 20:591-604.

Sundin, G.W. and N. Wang. 2018. Antibiotic resistance in plant-pathogenic bacteria. Annu. Rev. Phytopathol. 56:161-180.

Tansey, J.A., P. Vanaclocha, C. Monzo, M. Jones, and P.A. Stansly. 2017. Costs and benefits of insecticide and foliar nutrient applications to huanglongbing-infected citrus trees. Pest Manag. Sci. 73:904-916.

Trivedi, P., Y. Duan, and N. Wang. 2010. Huanglongbing, a systemic disease, restructures the bacterial community associated with citrus roots. Appl. Environ. Microbiol. 76:3427-3436.

Trotochaud, J. and R. Ehsani. 2016. Commercialscale thermotherapy for combating citrus greening (huanglongbing). 2016 ASABE Annu. Int. Meet. <https://swfrec.ifas.ufl.edu/hlb/database/ pdf/20_Trotochaud_16.pdf $>$.

Tsai, C.-H., T.-H. Hung, and H.-J. Su. 2013. An integrated management of citrus huanglongbing in Taiwan. Proc. 2013 Int. Symp. Insect Vectors Insect-Borne Dis. 193-210.

U.S. Department of Agriculture, Economic Research Service (USDA, ERS). 2018.

U.S. Department of Agriculture, National Agricultural Statistics Service (USDA, NASS). 2019.

Velasquez Guzman, J.C., S. Basu, R. Rabara, L.K. Huynh, G.C. Basu, H.B. Nguyen, and G. Gupta. 2018. Liposome delivery system of antimicrobial peptides against huanglongbing (HLB) citrus disease. Biophys. J. 114:266a.

Vreysen, M.J.B., A.S. Robinson, J. Hendrichs, and P. Kenmore. 2007. Area-wide integrated pest management (AW-IPM): Principles, practice and prospects. Area-wide control of insect pests. Springer, Dordrecht, The Netherlands.

Wang, N., E.A. Pierson, J.C. Setubal, J. Xu, J.G. Levy, Y. Zhang, J. Li, L.T. Rangel, and J. Martins, Jr. 2017. The Candidatus Liberibacter-host interface: Insights into pathogenesis mechanisms and disease control. Annu. Rev. Phytopathol. 55:451-482.

Warnert, J. 2012. Asian citrus psyllid and huanglongbing disease threaten California citrus. Calif. Agr. 66:127-130.

Wu, F., Z. Guan, and D.H. Suh. 2018a. The effects of tomato suspension agreements on market price dynamics and farm revenue. Appl. Econ. Perspect. Policy 40:316-332.

Wu, F., Z. Guan, and V. Whitaker. 2015. Optimizing yield distribution under biological and economic constraints: Florida strawberries as a model for perishable commodities. Agr. Syst. 141:113-120.

Wu, F., B. Qushim, M. Calle, and Z. Guan. 2018b. Government support in Mexican agriculture. Choices Mag. Food Farm Resour. 33:1-11.

Xia, Y., G. Ouyang, R.A. Sequeira, Y. Takeuchi, I. Baez, and J. Chen. 2011. A review of huanglongbing (citrus greening) management in citrus using nutritional approaches in China. Plant Health Prog. 12:24.

Yang, C., C.A. Powell, Y. Duan, R.G. Shatters, Y. Lin, and M. Zhang. 2016. Mitigating citrus huanglongbing via effective application of antimicrobial compounds and thermotherapy. Crop Prot. 84:150-158.

Yang, C., C.A. Powell, Y. Duan, R. Shatters, and M. Zhang. 2015. Antimicrobial nanoemulsion formulation with improved penetration of foliar spray through citrus leaf cuticles to control citrus huanglongbing. PLoS One 10:e0133826.

Zhang, L., S. Gao, D. Xie, and F. Zhang. 2016. Varying pulse control schemes for citrus huanglongbing epidemic model with general incidence. Commun. Math. Biol. Neurosci. 2016: Article ID 7.

Zhang, M., Y. Duan, L. Zhou, W.W. Turechek, E. Stover, and C.A. Powell. 2010. Screening molecules for control of citrus huanglongbing using an optimized regeneration system for 'Candidatus Liberibacter asiaticus'-infected periwinkle (Catharanthus roseus) cuttings. Phytopathology 100:239-245.

Zhang, M., Y. Guo, C.A. Powell, M.S. Doud, C. Yang, and Y. Duan. 2014. Effective antibiotics against 'Candidatus Liberibacter asiaticus' in HLB-affected citrus plants identified via the graft-based evaluation. PLoS One 9:e111032.

Zhang, M., C.A. Powell, Y. Guo, L. Benyon, and Y. Duan. 2013. Characterization of the microbial community structure in Candidatus Liberibacter asiaticus-infected citrus plants treated with antibiotics in the field. BMC Microbiol. 13:112.

Zhang, M., C.A. Powell, Y. Guo, M.S. Doud, and Y. Duan. 2012. A graft-based chemotherapy method for screening effective molecules and rescuing huanglongbing-affected citrus plants. Phytopathology 102:567-574.

Zhang, M., C.A. Powell, L. Zhou, Z. He, E. Stover, and Y. Duan. 2011. Chemical compounds effective against the citrus huanglongbing bacterium 'Candidatus Liberibacter asiaticus' in planta. Phytopathology 101:1097-1103.

Zhang, Y., J. Xu, N. Riera, T. Jin, J. Li, and N. Wang. 2017. Huanglongbing impairs the rhizosphere-torhizoplane enrichment process of the citrus rootassociated microbiome. Microbiome 5:97.

Zhang, M., C. Yang, C.A. Powell, P.B. Avery, J. Wang, Y. Huang, and Y. Duan. 2019. Field evaluation of integrated management for mitigating citrus huanglongbing in Florida. Front. Plant Sci. 9:1890. 